\title{
Click to Feed. Mobile Phone Applications' Role in Improving Food Access in Romania
}

\begin{abstract}
Ioana Ionita
Faculty of Sociology and Social Work, University of Bucharest - ioana daniela jelea@yahoo.com
\end{abstract}

\begin{abstract}
This paper explores the role of digital tools in surfacing and encouraging action against instances of social injustice in Romania, with a focus on food access. Starting from an analysis of developers/owners' motivations in creating a series of mobile phone applications combatting food waste, this research looks at digital tools' role in promoting the redis-

tribution of surplus food items that would otherwise go to waste. While acknowledging the limited scope of this endeavor, it is my suggestion that this form of Internet-based food activism is in its incipient stages in Romania and that it does not necessarily aim or have the force to induce social change for the moment.
\end{abstract}

Keywords: Food access, food justice, food aid, surplus redistribution, food sharing

\section{Clique para se Alimentar. O Papel das Aplicações Móveis na melhoria do acesso aos alimentos na Roménia}

\section{Sumário}

Este artigo explora o papel das ferramentas digitais no aparecimento e no incentivo à ação contra instâncias de injustiça social na Roménia, com ênfase no acesso a alimentos. A partir de uma análise das motivações dos desenvolvedores/proprietários de uma série de aplicativos para telemóvel que combatem o desperdício de comida, esta pesquisa analisa o papel das ferramentas digitais na pro- moção da redistribuição de excedentes de alimentos que seriam desperdiçados. Embora reconhecendo o âmbito limitado deste esforço, é minha ideia que esta forma de ativismo alimentar baseada na Internet esteja nos seus estágios iniciais na Roménia e que não visa necessariamente ou tenha força para induzir, neste momento, mudança social.

Palavras-chave: Acesso a alimentos, justiça alimentar, ajuda alimentar, redistribuição de excedentes, partilha de alimentos 
This is an exploratory, qualitative study of the extent to which digital tools available to the Romanian public help improve access to food for those at hunger risk by allowing a redistribution of surplus resources. This research focuses on four mobile phone applications self-described as combating food waste in Romania. The findings reflected herein are based on semi-structured interviews conducted with the developers/owners of such applications, as well as on my fieldwork as volunteer within a charitable organization that runs a soup kitchen providing cooked meals for a group of homeless and undocumented people in Bucharest. The applications considered here are the only digital tools of this kind available to the Romanian public; foodsaving mobile applications created by Romanian developers, but not available to Romanian consumers are outside the scope of this research.

With the caveat that more research is necessary as the local context around food waste and food redistribution evolves, it is my suggestion that, despite being able to set up communication channels between potential donors and beneficiaries, mobile phone applications' role in improving food access is severely limited by the legislative, bureaucratic and infrastructure impediments that stand in the way of creating a sustainable circuit of surplus redistribution.

\section{FOOD WASTE AND HUNGER. A THEORETICAL BACKGROUND}

Despite their relatively short history under the Food Studies umbrella - the first attempt to "[...] collectively [...] frame potential sociological approaches to understanding food waste" (Evans, Campbell, \& Murcott, 2013, p. 5) happened just five years ago - food waste and food saving have fuelled a consistent number of research initiatives.

One such initiative focuses on food saving in Australia, where the "freegan" or "dumpster diver" communities appear to be the adepts of an "alternative ethics of consumption" (Edwards \& Mercer, 2013, p. 175). Acting within an environment which has the characteristics of what previous research has dubbed an "autonomous food space" (Wilson, 2012), "freegans" and "dumpster divers" use their senses in

order to recuperate discarded food items that would officially be unacceptable to NGOs or other organizations that might otherwise use them to feed those living in precarious circumstances (Edwards \& Mercer, 2013). 
Within the context of consumers being empowered to decide what to buy and eat, researchers have also focused on food labeling for food safety purposes, an element whose role evolved from a proof of freshness to nutritional content indicator and, finally, to a guarantee that the respective products are fit for human consumption (Milne, 2013). Also, discussions around the reliability of mentions such as "expiry date" and "best before" brought about a debate as to the relationship between food safety regulations and consumers' own practical experience in assessing the state of and risks associated with consuming perishable food (Milne, 2013).

Efforts have also been made to better understand the power relations, institutions and social conventions at work in the production, representation and regulation of food waste, with a focus on the role that food aid, technological developments and legal/political factors have in generating such waste (Gille, 2013).

In addition to that, the mechanisms whereby discarded food that has not reached the bin yet is construed as "capitalist surplus" rather than as a mere disposable matter have also sparked interest (O'Brien, 2013). O'Brien's analysis of the way waste is "imagined", and regulated within the framework of the European waste policy leads to the conclusion that:

alternative arrangements for exploiting materials of all kinds [...] involve unsanctioned agents of transformation and distribution of material residues whose actions negate both the compliance mechanisms that effect the 'lasting transformation' of non-wage labour into wage labour and the normative mechanisms by which capitalist exchange accrues value for capitalists. (p. 207)

The theoretical background outlined so far is relevant for the purposes of the present research in that it sets the stage for two lines of inquiry: who decides that a food item is still fit for consumption and when (the regulation versus senses dilemma), and, at what point, if ever, a food item in danger of becoming waste escapes its market value "curse" and can move freely, to be given away, as a gift or donation.

Another concept relevant for this discussion is that of "distributional justice", which sees food access as a matter of politics and policy, and a responsibility of the State structures, that should not be mistaken as covered by the occasional, targeted food charity efforts undertaken in soup kitchens, for instance (Riches \& Silvasti, 2004, pp. 3-4). Two other perspectives add to the variety of approaches in the matter of food access: combatting poverty and hunger is a matter of getting support from 
one's community and access to a minimum income covering basic needs and access to food is tightly connected to the economic development of the community and to the sustainability of its food production and distribution systems (Levkoe, 2006).

This study takes over some of the issues under the distributional justice umbrella, namely: the question of responsibility towards the environment and towards those at hunger risk when setting forth a food waste management framework and the issue of long-term sustainability of a system which aims to redistribute food surplus to those in need. Also, the matter of community support in hunger-combatting efforts was considered when exploring the application developers/owners perception of a possible tension between the commercial and the charitable aspects of reducing food waste.

Several concepts have come to clarify the conditions under which the right to food is adequately exercised. "Food poverty", for instance, encompasses the underlying state of hunger and the context of food security/insecurity (Riches \& Silvasti, 2014, p. 5). Being food poor is also frequently associated with a disregard for one's dignity and right to choose, especially when it is countered via emergency or alternative food aid actions: "Food banks, soup kitchens and breadlines are not socially accepted ways to acquire food for oneself or for the family in the developed world, nor is begging, shoplifting or dumpster diving, that is searching for thrown away food in skips." (Riches \& Silvasti, 2014, p. 6).

Following the same logic, food security exists "[...] when all people, at all times, have physical, social and economic access to sufficient, safe and nutritious food which meets their dietary needs and food preferences for an active and healthy life" (Riches \& Silvasti, 2014, p.6); on the other hand, "food insecurity" involves "[...] limited or uncertain availability of nutritionally adequate and safe foods or limited or uncertain ability to acquire acceptable foods in socially acceptable ways." (Riches \& Silvasti, 2014, p. 6).

Debates over the compatibility of emergency food aid systems and the principles under the right to food umbrella have pointed out that beneficiaries of such systems are maintained in a state of dependency because the underlying cause of their lack of access to food - namely social inequality - is never actually tackled (Poppendieck, 1998). As pointed out by Tarasuk \& Eakin (cited in Lambie-Mumford, 2017), these systems also deprive beneficiaries of dietary options as well as of all the other benefits of the paying consumer status: 
[...] [in] the mainstream food system [...] affluent consumers can choose from literally thousands of different (or seemingly different) food products, marketers bombard them with claims about the virtues of particular product ingredients, and values such as visual perfection, freshness and convenience reign supreme. (p. 79)

The present paper takes over and builds upon two elements pointed out in the academic literature dedicated to emergency food aid referred to above, namely: the social acceptability of food received in times of need as well as the absence of choice in the opposition consumer vs. food aid beneficiary. These were starting points for an exploration of informants' perception of the value/quality of food sold on a discount, of their personal convictions related to the provision of food aid as a community's duty towards its members and of the possible reflection of those convictions in the way the analyzed food saving mobile phone applications were built and function.

\section{FIGHTING FOOD WASTE WHILE FEEDING THE HUNGRY IN THE DIGITAL WORLD}

\section{Communication and Activism}

Two main directions are distinguishable in the discussion around the role of information technology in enabling or influencing access to food: digital tools' role in enhancing communication speed and scale, and their contribution in helping aggregate communities and driving action.

On the communication side, social media platforms have been singled out as essential tools in blurring the lines between "professionalism versus amateurism, publicity versus privacy, and business versus pleasure" (Rousseau, 2013, p. xiii) when it comes to discussing/assessing one's own experience of cooking/eating. In addition to "some sort of validation and appreciation" that food-themed social media interactions offer, they have been found to help create a sense of community the manifestations of which sometimes exceed the gastronomic realm, as followers and fans ex-

press their support in difficult situations experienced by prominent online socialites (Rousseau, 2013, p. 36).

Laying a stronger emphasis on the idea of common action ensuing from the creation of a community with its particular agenda, "digital food activism" (Schneider, 
Eli, Dolan, \& Ulijaszek, 2018, p. 3) sees digital tools as helping “[...] redefine and/ or expand food transparency, and [...] disseminate otherwise 'hidden' information to citizen-consumers who may share these concerns." (Schneider et al., 2018, p.1). Moreover, this form of activism can transform food into a "means to broader political action", going as far as "changing the market relations" by providing consumers with information that will influence their food purchase habits and preferences (Schneider et al., 2018, p. 215).

Narrowing the focus to food access and poverty, a study into Twitter's role in raising awareness and offering solutions to food scarcity issues in Australia has pointed out the microblogging platform's role in reflecting both the fallacies of communication across the spectrum of actors interested in combatting hunger (influencers, NGOs, media, etc.) and the variegated nature of the issues associated with the right to food umbrella theme (Mann, 2018). While reflecting on how "[...] digital media platforms and applications contribute to the shaping of public issues and the democratisation of public spheres", this study also points out the need for further research to also capture "marginalized" voices as well as their perspective on key food scarcity issues (Mann, 2018, p. 180).

Though quite limited in scope at this point, the present research could develop a stronger connection to the digital activism domain, but only as the digital tools considered here start making a difference in the Romanian public's perception about food waste and food surplus redistribution. Defined as "[...] an organized public effort, making collective claim(s) on a target authority, in which civic initiators or supporters use digital media" (Edwards, Howard, \& Joyce, 2013, cited in Schneider, Eli, Dolan, \& Ulijaszek, 2018, p.10), digital activism remains, for the moment, too big of a hat for these tools. Instead, a more appropriate theoretical architecture that would support the case studies included in this paper would be a rudimentary form of "Internet-enhanced food activism". This concept would combine food activism, seen as "[...] efforts by people to change the food system across the globe by modifying how they produce, distribute, and/ or consume food" (Counihan \& Siniscalchi, 2014, cited in Schneider et al., 2018, p. iii) with one of the terms in the Internet-based vs Internet-enhanced activism dichotomy (Vegh, 2003, cited in Schneider et al., 2018, p. 8). Given that these tools aim to educate the Romanian public about what it means to redistribute one's own surplus, and to trigger a re-categorization of food that is about to expire from waste/garbage to usable food resources, it could also be argued that they are also on their way to forming "[...] infrastructures that give rise to on- 
tological experiments" (Jensen \& Morita, 2015 cited in Schneider et al., 2018, p. 3).

The elements related to food-themed digital communication and activism informed the discussion about the choice of qualifiers when presenting, from a marketing perspective, the food items distributed via the Romanian food-saving apps (food on discount, saved/recovered waste, fresh food at affordable prices, food deals, etc.). This was also the background of questions related to the application owners/ developers own perception and, possibly, use of food going through an accelerated sale process.

\section{Digital Maps and Food Access}

An important aspect of digital tools' role in enabling wider access to food is the existence of digital maps highlighting offline sources of affordable food.

For the so-called "food deserts" - urban areas with inadequate access to financially accessible and healthy food (Cummins \& Macintyre, 1999), - these maps were thought to be a solution, as they would help solve the diet-driven health issues experienced by precarious communities. One digital step further, proposals have been made to combine these maps with a form of "geographic tracking on daily mobility created using Global Positioning System [...] software on a smartphone" (Shannon, 2015 , p.85) thereby acknowledging that low-income households rely on more factors than the mere spatial proximity to a store or a market in devising their food procurement routines and preferences (Shannon, 2015).

Digital maps are also at the core of the various food sharing variants that exist under the vast sharing economy umbrella. A study commissioned by the UK Minister of State for Business, Enterprise and Energy pointed out the existence of several digitally-enabled activities focused on the production and distribution of affordable food (Wosskow, 2014). These activities rely on some form of digital map to connect food producers to beneficiaries in different circumstances: land-sharing for those who want to grow their own food, connecting buyers to farmers directly, for order placement, without the need for a store or a market, sharing one's own cooked meal or an extra portion with the elderly in the area, etc. (Wosskow, 2014, p. 36).

Digital tools also play a role in satisfying a concern for the sustainability of food chains - in addition to waste reduction - as surplus is shared with or redistributed to those in need. Under the "sustainable innovation that meets precarious lifestyles" theme (Broadbent \& Cara, 2018, p. 7), a joint UK and Italy study lists several categories of projects that use a digital platform to ensure that overabundant food reaches 
"fragile people" (Broadbent \& Cara, 2018, p. 8). This list contains, among others, mobile applications providing information on available stocks to be donated by businesses (Olio, Foodcloud, Bonapp, the Real Junk Food Project), as well as urban foraging and growing maps (Lend and Tend, 3000 acres, Sow the City, the Big Dig, Plantez chez Nous) (Broadbent \& Cara, 2018, p. 8). Relying on prior findings around the transformative power of networks on markets and freedom, Broadbent and Cara point out that "the open, distributed, connected, nature of the web" works "as a way to dis-intermediate the relation between producer and customer" and helps "create new networks of exchange and knowledge, or [...] blur the boundaries between producers and users" (Benkler, 2006, cited in Broadbent \& Cara, 2018, p. 3).

As all of the applications considered in this study aim to better connect, via digital maps, those who make/own food and those who need it, it was important to understand, in the discussions with informants, in their capacity as designers of the food procurement experience, what options, if any, those maps offered users for the customization of their searches based on their food preferences/search history. Another important area to explore, in this context, was to what extent Romanian food-saving applications are profit-driven and how much room for free-of-charge food sharing is left in their current or future development plans.

\section{FOOD SURPLUS. COULD IT FEED THE HUNGRY?}

\section{How Do Others Do It?}

Within the global digital landscape dedicated to redirecting food surplus to those in need, one of the most important projects, both due to its scale and ambitious purposes, is the ReFed initiative in the US, which brings together tech, business and political actors to find innovative ways of reducing food waste. One of the featured directions of interest on the ReFed website is that of "donation-matching software", which would not only facilitate the documentation of large food donations coming from companies, but also, the recovery of smaller batches of food available at restaurants, cafes or supermarkets, the handling, storage, transportation and distribution of which would be too expensive for NGOs, but worthwhile for individuals looking for affordable food ("Donation Matching Software", 2018). Such software is not completely absent at this point, but it could use further development. For instance, relying on the financial support coming from Google, Feeding America, "the larg- 
est hunger-relief organization in the United States", operates an online marketplace which connects food donors to food banks and other such food distribution organizations (Feeding America, 2014). On a smaller scale, ReFed promotes several food recovery applications - Spoiler Alert, Zero Percent, Copia, Community Plates, and Food Cowboy - which help private individuals get access to excess food that businesses are willing to donate ("Donation Matching Software", 2018).

Saving food by selling it at a discount before it goes to waste is a business idea that caught on in other parts of the world. Sometimes incorporating a stock management component, which helps businesses keep track of expiry dates and apply discounts as soon as possible, these applications support a wider access to food by temporarily lowering food prices. JustNow, which enables access to discounted fresh produce in supermarkets, and Chowberry, which generates discounts for a wider variety of food items (Lo, 2018) are both based in Africa; a similar application, Zéro-Gâchis ("ZéroGâchis, qu'est ce que c'est ?", 2011-2016), is available to French customers.

Selling cooked food at a discount is another strategy that works across Europe. Some examples are OptiMiam, available in France ("Lachat du 'juste à temps' pour réduire le gaspillage alimentaire", 2018), Too Good To Go, which covers Belgium, Denmark, France, Germany, Netherlands, Norway, Switzerland (with a global version as well) ("We're Too Good To Go", n.d.), and YourLocal, available in UK, Denmark and Germany ("Fight food waste and support local shops", 2018).

\section{Romania: The Ecological Perspective}

Though progress has been made in this direction, there is still no clear understanding of the proportions of the food waste phenomenon in Romania. As shown in Table 1, according to data collected at the level of the European Union (data available for the year 2016, but extracted in April 2018, with the next update scheduled for July 2018), Romania would rank last but one in point of municipal waste per capita (Eurostat, 2016). 


\section{Table 1 - Municipal waste generated by country in 2005 and 2016, sorted by 2016 level (kg per capita)}

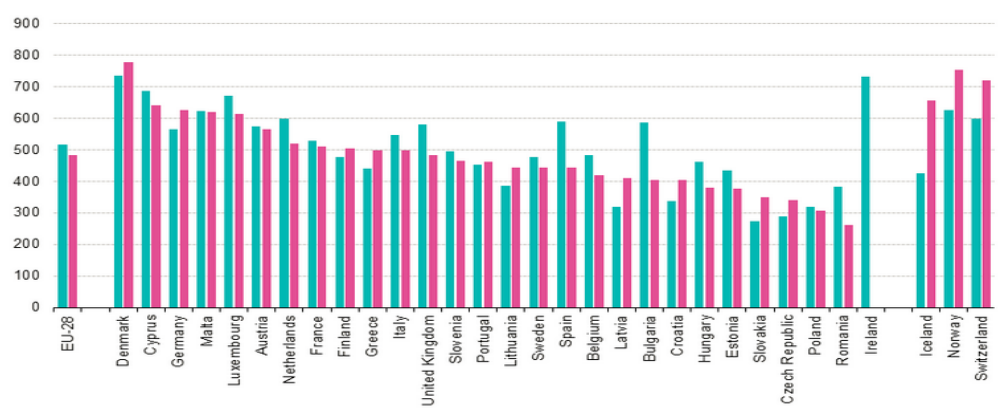

$=2005=2016$

Reprinted from: http://ec.europa.eu/eurostat/statistics-explained/index.php/Waste statistics @(1995-2013) by European Union

However, this data covers, according to the Eurostat definition, “[...] waste collected by or on behalf of municipal authorities and disposed of through waste management systems.", "[...] mainly [...] waste generated by households, although it also includes similar waste from sources such as shops, offices and public institutions." (Eurostat, 2016). Therefore, no specific EU-level view of food waste is available for the moment either.

Food Waste Romania, a project financed by the Swiss Romanian Cooperation Program and developed together with the Mai Mult Verde Association, offers a rough estimate of this phenomenon, stating that approximately a third of the Romanian food products, a total of 2.55 million tons, get thrown away per year ("What is Food Waste?", 2016). However, these figures are to be taken with a grain of salt according to a note on the methodology behind these estimates that appears on the Food Waste Romania dedicated website:

At this moment, there is no large-scale study done on over 1 million people [in Romania]. The most recent figures are based on surveys and estimates provided by various players in the food production industry. [...] For household waste, the most accurate estimate is a study done in Great Britain, covering 2,000 households.

("What is Food Waste?", 2016) 
In 2017, Mai Mult Verde Association and the Resource Center for Civic Participation $(\mathrm{CeRe})$ released the results of an experimental study on food waste at consumer level, which reveals two key facts behind the 129 kilograms of food thrown away by each Romanian per year (as per data provided by the Romanian Ministry of Agriculture for the year 2016) ("Romania Against Food Waste," 2017, p. 5). On the one hand, the top two positions in a hierarchy of consumer-generated food waste in Romania are occupied by cooked food and fresh produce (fruits and vegetables) ("Romania Against Food Waste," 2017, p.15); on the other hand, the main reason why these categories of foods go to waste is excessive buying ("Romania Against Food Waste," 2017, p. 16).

\section{Romania: The Legal Point of View}

Combatting food waste while also tending to the needs of those at hunger risk is a relatively recent preoccupation of the ecology-minded population in Romania. From a legal point of view, this is still an issue pending an official resolution as the road from project to reality of the actual mechanisms whereby food producers/distributors/retailers are to dispose of their food surplus so that it does not become a source of pollution is quite sinuous. The Romanian Parliament adopted an anti-food-waste law in the early months of 2016 but postponed its enforcement until December 2017. A new delay was caused by the legislators' difficulties in setting forth the mandatory accompanying set of norms of enforcement, so that this piece of legislation was to come into effect in July 2018.

In brief, the Romanian anti-food waste law provides that a system be devised for the monitoring of the food surplus (defined as food about to reach its expiry date) that economic operators (food manufacturing, processing, distribution, hotels and restaurants, as well as all businesses offering food services) have to deal with, and that such food be offered for sale at a discount or voluntarily registered for redistribution (via a centralized State Authority) to NGOs and other non-profit entities which specifically provide welfare services. In this scenario, the window of opportunity for donations would start as early as a few days before the food's best before date and it would end as late as 2 days to 2 weeks after such date (depending on the food category), provided that it is still fit for human consumption. The food offered via this system would be legally construed as a gift or a form of sponsorship. If no beneficiary is found for such donations, the concerned businesses would have to reach out to organizations catering to the needs of animals. If no animal shelter or other such or- 
ganization commits to taking over the respective food, then measures are to be taken for the waste matter to be turned into compost.

One of the aspects that sparked controversies in the discussions between the Romanian Minister of Agriculture and Rural Development, representatives of the food manufacturing/food retailer industries and the social actors potentially interested in taking over food surplus is the fact that, in its earlier versions, the law offered the economic actors, NGOs, associations and social enterprises the possibility of selling food that could/has been donated in this way. To this end, the law initially set price ranges that both sides were to abide by. Economic actors might, for instance choose to offer NGOs food that fell under the scope of the anti-waste law at a "[...] a maximum of $3 \%+$ VAT of the purchase price, in the case of retailers, and of $3 \%+$ VAT of the manufacturing price for manufacturers and processors" ("Law 217 of 2016 concerning the reduction of food waste," 2016). On the other hand, the entities on the receiving end of food donations would, in their turn, have been allowed to resell the respective items for " [...] a maximum of $25 \%+$ VAT of the purchase price, for foods taken over from retailers, and for a maximum of $25 \%+$ VAT of the manufacturing price, for food taken over from manufacturers or processors." ("Law 217 of 2016 concerning the reduction of food waste," 2016).

During negotiations with the legislators, fears were expressed that this waste reduction mechanism might be transformed into a tax avoidance scheme, that fraudulent non-profit entities might disregard the safety of food distributed so close to its expiry date and that the economic entities that own this food might see their property right injured by legal provisions "forcing" them to simply give it away after a specific point in time.

Two points of contention seem to surface here: price and trust. As long as the food still bore some commercial value, expressed through the setting of a price, strong competing arguments made commercialization fair game for both economic and social actors. It appears that the provision allowing social actors to sell donated food is the result of a proposal made, among others, by Simon Suitner, manager of the Somaro social store in Bucharest. Suitner aimed to ensure a form of financing for enterprises like his, as selling donated food would allow him to cover the operating costs of the store he is managing. In an interview with him taken during the summer of 2017, he also invoked reasons having to do with a respect for beneficiaries' dignity (paying, even the smallest price, allows them to choose what they eat) and with promoting a form of responsible consumption (a budget limitation would encourage beneficiaries 
to think more about their dietary choices as opposed to being handed over any food as a form of donation).

This perspective clashes with that expressed by the representative of Romalimenta, the Romanian Food Industry Patronage Federation:

The law encourages you to sell the products before the expiry date. This does not mean promoting or eliminating waste. Moreover, reducing the price so much usually fuels waste. Yet, the problem that bothers me with this law is the creation, be it by ignorance or intentionally, of a parallel market. That is very risky. In a country where we keep complaining about tax evasion, should we go ahead and create a parallel market? It takes a really brilliant mind to do this, doesn't it? (Breniuc, November 2016)

On the matter of trust, a new battlefield is opened, with concepts such as "sell by", "use by" and "best before" dates as the sore points each party invokes. On the one hand, there is the Romalimenta representative fearing the impact that linking a food poisoning outbreak to a specific food brand might have:

We're caught between a rock and a hard place. If I take the risk of offering for consumption foods that are close to their expiry date or oddly shaped and something happens to those who eat them, I won't get any applause for reducing food waste and helping some people get fed. On the contrary: I'll get a fine! And if there's a case of food poisoning and the press gets a hold of it, they'll immediately find out what shop that food came from, what brand it was, and all hell will break loose with them saying that the salami made by brand $\mathrm{x}$ has caused I don't know how many elderly people in a home facility to fall ill. There's no telling where the loss ends here. (Breniuc, November 2016)

On the other hand, there is Simon Suitner's and the Somaro chain's experience with food safety and selling expired food items within a reasonable time without any risks to the health of beneficiaries in Austria. Oana Niculaie, an expert of the Romanian Food Bioresource Institute, pinpoints the problem at the heart of this conflict: "It's not the strictness of the law that is to blame here [..] but the fact that Romanian legislation considers any food item that has exceeded it expiry date as being garbage, therefore indirectly encouraging consumption and waste." (Breniuc, June 2016). 
The anti-food waste legislative saga continues. In June 2018, the Romanian Chamber of Deputies adopted a proposal for amendments to Law 217/2016 which not only made it optional for economic agents to donate food that is about to expire, forbade the re-selling of such merchandise, and completely transferred the logistics burden onto the recipients of possible donations ("Law Project for the amendment of Law 217 of 2016 concerning the reduction of food waste," 2018). The anti-food law is now suspended until January $1^{\text {st }}, 2019$.

These discussions are relevant for the purposes of this research from two perspectives. On the one hand, the possibility of monetizing food surplus to such an extreme, as set by the law, drastically limits the timeframe within which food that is in danger of becoming a waste matter, but would still be fit for human consumption, can actually be donated. Thus, in cases where the donated food would have to reach and be consumed by its human beneficiaries within less than a week, donations remain only theoretically possible due to the bureaucracy (documents attesting the origin of food items and their fit-for-human-consumption status) and infrastructure impediments (permanent staff and means of transportation that would only sporadically be used). Moreover, given the lack of predictability of the frequency and size of donations, as well as the fact that the non-profit entities that would access these food sources should exclusively bear the connected logistics burden, this system of donations would, actually, be wasting valuable and, most of the times, limited, resources that the NGO sector struggles to secure. On the other hand, the law reflects a food waste reduction strategy which does not seem to lay too heavy a focus on issues of social solidarity or to encourage corporate responsibility actions via monetary incentives, such as tax deductions.

\section{Romania: The Digital Perspective}

In the first quarter of 2017, Romania was overturned as European leader in point of internet speed by Sweden, while still ranking among the top ten countries with the highest mobile internet speed worldwide, according to the Q1 2017 State of the Internet / Connectivity Report released by American company Akamai (Akamai, 2017). Despite these impressive figures, Romania still has some important steps to take in enabling its population to take advantage of digital instruments. According to a 2017 World Bank Report on the role of the internet in local development, Romania has one of the "lowest levels of [online] interaction with the government and online submission of completed forms" (WB, 2017, p.23), and a 30 percentage points rural-urban 
disparity in Internet access (WB, 2017, p.29). Also, less than 50\% of the Romanian population access the Internet daily (WB, 2017, p.35), while less than half of Romanian companies are present online (WB, 2017, p.40). To complete this overview of the digital Romania in figures, a Statista estimate places the proportion of monthly mobile internet users at a little over $50 \%$ by 2022 (Statista, 2018).

A few projects explicitly dealing with food waste are present online with their own web pages and social media properties. Waste Food Romania has a dedicated Facebook page with almost 3,300 followers, whereas Mai Mult Verde Association, the main partner in the Waste Food Romania project, and which covers a wide range of ecological issues, reaches 57,000 followers on the same platform. Food Waste Combat, an initiative of the Junior Chambers International in Cluj, Romania, has a Facebook followership of approximately 3,200 people.

Association X (where the author has volunteered and done participant observation) documents on Facebook, before a followership of close to 11,000 people, volunteers' cooking sessions for the benefit of those in need. The association promotes the idea of cooking on a budget, with seasonal and local ingredients, as a form of community support for the homeless and for other categories of people at hunger risk.

A form of online activism specifically dealing with the connection between food waste and food access for those in need was recently initiated by the Resource Centre for Public Participation (CeRe), an NGO aiming to make the public's voice heard to the governing authorities in cooperation with the Somaro social store. In fact, as a reaction to the proposed changes to the anti-food-waste law that were to be voted on by the Romanian Chamber of Deputies, CeRe and Somaro launched on June 21, 2018 an online petition inviting all concerned social actors to sign for last-minute (and very unlikely) improvements that would set economic actors obligation, not option, to donate surplus food that could not be sold on discount and a reversal of the interdiction against social stores re-selling donated food at very low prices (CeRe \& Somaro, 2018).

Under a wider ecology umbrella, Green Report, an online news platform specializing in environment and responsible consumption topics, also communicates with a community of close to 9,000 people on Facebook. Association Social Trading Urban Place supports, together with the Lidl retailer, Oily (in Romanian Uleiosul), a project dedicated to the responsible collection of used cooking oil, followed by close to 9,300 people on Facebook. Also, a public group entitled Centre for Responsible Consumption occasionally approaches the topic of food waste before a community of approximately 1,300 people. 


\section{ROMANIAN FOOD SAVING MOBILE APPS. THE SELL VERSUS DONATE DILEMMA}

As food saving is highly dependent on matters of temporal and spatial proximity to the source of such food as well as on the mobility of its recipients, mobile phone applications appear to be the ideal digital communication tool that would allow users to be at the right place and at the right time for this kind of food transfers to occur.

Four mobile phone apps have been considered for the purposes of this section of the research. App $1^{1}$ is an application in the late development stages, which aims to support restaurants, supermarkets sell the cooked food they have left at the end of the day to willing customers within a specific radius of their location. While App 1 will first be made available to users in Bucharest, App 2, a mobile phone application now sunset and which was designed around a similar mission, was active for a few months in Cluj, the second main Romanian IT hub. The third application considered (App 3) proposes a concept previously tested in Africa, namely saving food by enabling users to get the best deals on fresh produce via notifications about discounted merchandise from large retailers. Finally, there is App 4, an application created by the Association $\mathrm{X}$ with the purpose of connecting donors and beneficiaries (legal entities, not individuals) for a smoother transfer of surplus food.

This research combines the perspectives of two startups (App 1 and App 2), one taking its first steps, the other having already ended its activity with that of a corporate franchise (App 3), with an already tested operating mechanism and extensive experience, though within a different cultural environment. Considering the lengthy discussions around the re-selling of donated food that were triggered by the Romanian anti-food-waste legislative process, this set of applications also covers the entire "sell versus donate" spectrum: while the first three play(ed) the food surplus monetization card, App 4 is exclusively interested in donations.

From the point of view of their operating model, the applications the primary purpose of which is monetization offer their users a map or feed-like interface, where they can see, in various degrees of detail, what type of food is being offered, when it would expire, how far away from the user's location it is and how it should be picked up. Some of these applications also offer or are considering offering users a system of personal-

1 All applications and informants have been anonymized out of concern for the influence that this study might have on them from a business perspective (funding for startups, adoption for the more mature projects, etc). Applications will be identified as App 1/2/3/4; owners/developers will be identified as C App 1/2/3/4. 
ized notifications, based either on their history of returning to a store/restaurant or on food preferences. Different from other food sales channels, these applications are understood as offering a limited range of items (users cannot order something other than what is posted), within specific time frames (when food is close to its expiry date, but also towards the end of normal business hours), and without the option of having the food delivered. In the case of App 4, beneficiaries do not have an option to express preferences; donors offer whatever they have available, with beneficiaries being notified automatically about any offer placed within their respective geographic area (the same city).

From a commercial point of view, App 1 and App 2 work(ed) on a commission per order model, while App 3 is promoted as a smart mobile advertising tool. App 4 is completely free of charge, with setup and possible developments done on an exclusive volunteering basis.

In developing this portion of the research, the aim was to determine the personal motivations behind the creation of these applications and whether a social solidarity ingredient was present in addition to the apparent ecological drive. Another purpose was to explore whether an ethical dilemma ever arose in the minds of the application creators in the matter of selling versus donating excess food. A collateral topic of interest was the application creators' own experience with their public's awareness and understanding of the acceptability of food sold on discount and of food waste.

On the subject of motivations, a first path explored was whether personal beliefs and/or practices/experiences played a role in the application creators/owners' decision to take on a food waste project. A common element in all testimonies on this subject is that all interlocutors know or have used a similar application in another country and decided to bring it over to Romanian soil as well. They see this as their contribution to Romania's synchronizing with global or European trends in this domain. However, contextual elements revealed each project owner's specific angle in approaching the matter of food waste.

For C App 1, living as a student abroad came with the realization that food waste is a reality very close to home:

Mom would send us packs of food all the way from Romania to Denmark - I think it took almost two days for it to reach us - and [...] we'd throw away that food and feel a sort of ...discomfort. So, we said to ourselves: we've got this thing that is happening to us and we've also got this part where we know we can do something good for the environment. (C App 1) 
As a consequence of this and following her exposure to the use of the Too Good To Go mobile application in procuring food on a daily basis in Denmark, she not only embarked, together with her brother, on the journey of building App 1, but also apparently changed her own consumption practices:

Once we realized the magnitude of the problem, that is once we'd done our research [...] yeah, we started [eating food sold at a discount, my note]: the fruit that they sell in the supermarket and it's not that good looking, but it's good to eat, it tastes the same. (C App 1)

In the discussion with C App 2, time surfaced as an important additional theme in his food saving activity:

We [the project team - my note] saw where other people were heading to abroad, and we said to ourselves it's not worth waiting for them to come here as well and that it would be good to have our own product, a Romanian app. (C App 2)

The idea of wasting time sprang up again when he was asked whether he would buy food on discount, therefore qualifying as a potential user of his own application. In fact, he is not a discount hunter because chasing deals takes up a portion of time that he would rather use in a different way.

For C App 3, it was a matter of providing an alternative to the on-and-off solution NGOs were offering to the food saving issue:

The problem with the way an NGO would do things is that it is not sustainable, most of the times, because [the NGO - my note] would need to look for money, sources of financing, after a while, and the costs incurred by retailers are quite high - you've got a logistics cost, you need to donate, you must set up some systems that need to be synchronized ... the IT is always lagging behind- so [said NGO - my note ] could not do this efficiently and, retailers would rather throw [food] away instead of covering those logistics costs. (C App 3)

In the case of App 4, the owner of which is also a founding member of Association $\mathrm{X}$, there was, primarily, a communication need that had to be met. With the increase 
in awareness about the association's activity - providing cooked meals to those in need - there came the additional task of directing various food donors to potential beneficiaries. Hence, App 4 simply sticks to connecting donors to beneficiaries, with the legal, food safety and logistics details of the food transfer as the exclusive responsibility of the parties that come into contact in this way.

When approaching the subject of "saved" food redistribution to those in need, it became apparent that none of the application creators had initially aimed to tackle this issue as well, and that not seeing food thrown away was their ultimate purpose.

In the case of App 1, there is, currently, no specific option to donate food that cannot be monetized by the end of the day. The founders of the application do not see its existence as "pushing" businesses, in any way, towards selling their food up until the last moment rather than donating it:

We spoke to certain restaurants and they said they donate [excess food - my note] to the Church, [they- my note] donate it to children. [...] We did not try to push it: "Come on, there's money to be made from it!". Is that food saved from the bin? Yes! That's what matters the most to us. If you want to sell the food, we'll help you; if you want to donate it, we'll also help with that, but first, let's monetize it! (C App 1)

With App 2, the creators' focus on a very quick implementation and their expectations of seeing it being effortlessly integrated in businesses' daily operations led to a lot of frustration, and caused them to reject the idea of putting in even more work for the accomplishment of this extra charitable purpose:

The distance between expectations and reality was so big that we got fed up and we threw everything away. Somehow, we were offering a tool that was only doing good to everyone involved, but we were the only ones doing the hard work to keep everyone happy. (C App 2)

In addition to this, according to C App 2's account of a discussion with a restaurant owner, donations would have come with additional responsibility and costs that were not worth taking on: 
Look, guys, to be honest with you, I'm making so much money that I really don't need the change that I would make from selling what I throw away. If you want, come over, and I'll give you all the food; it won't be a donation, we need too many certifications... I'll simply give it to you and you can do whatever you want with it. (C App 2)

Therefore, in the absence of any other incentives to donate, a leaner process whereby excess would be transferred would have made a difference.

In the case of App 4, the strongest arguments against its involvement in the actual donation process is the combination between the legal maze to be navigated and the lack of resources. C App 4 sees food saving and feeding those at hunger risk as two separate issues, which, though theoretically conceivable as two ends of the surplus food redistribution process, cannot be approached as such by the association behind App 4:

Beneficiaries will never be able to say, for instance: 'I need 50 soups!'. The one who initiates [the transfer - my note] is the one who has some food left. This is not a matter of solving a social issue [...], feeding the hungry. This is about combatting food waste. (C App 4)

With App 3, the idea of donating food appears to be clashing, for the moment, with the priority of solving a cost issue:

In the absence of a clear source of financing - usually, with NGOs, financing is focused on projects and missions, it does not work as a continuous process so that you can plan and make your expenses sustainable for several years - someone will have to bear the costs, and, most of the times, that someone is either the State or the retail sector. (C App 3)

In fact, C App 3 sees a cooperation with NGOs - the sharing of maps of available discounted food sources -, as possible, but only after the application has gathered a critical mass of users. For the moment, App 3 is only indirectly involved in CSR actions that would see teams of corporate workers cook on a budget, as a team-building exercise, with the option of donating the resulting meals to homes for the elderly or to other similar institutions. 
When touching upon the possible tension between the act of selling and that of donating food that is close to its expiry date, C App 3 acknowledged that this is not a clear-cut choice and, in keeping with his focus on cost, presented the act of buying as somehow more dignified/safer than the one of receiving a food gift:

When it comes to donations, there's the matter of the fuzzy ownership of responsibility in case somebody falls sick because of something that they ate [from a donation - my note]. [...] Who's to bear the costs? There's also a social aspect in that the people who would need the food feel more...well, it's more decent to buy food at a very low price than to have it handed over to you by someone. (C App 3)

Finally, the interviews touched upon perceptions about discounted food and food waste. Whether these accounts are true to fact or they express the application creators/owners' expectations concerning their potential users' profiles depends, to a certain extent, on how long these tools have been in use and on their capacity to collect user feedback.

App 1 currently has 300 potential users, in fact, the application owners' friends and relatives, who have downloaded it for testing purposes. According to C App 1, one category of expected frequent users would be students who, being on a tight budget, would get access to a meal that is otherwise financially inaccessible, and which theoretically has the same nutritional qualities as the fully priced one. She referred to this group as „discount hunters, socially responsible”. She also expects that App 1 users would be corporate workers who do not have time to cook and who pick up food offers on their way home.

With App 2, the owner's experience revealed that selling food on a discount might be perceived as damaging to the food producers' brand image:

[...] at the beginning the whole concept was introduced as 'Help the planet! Save the planet!'. Somehow, [ App 2 - my note] was about reducing food waste. [...] Later, very many restaurants came to us and said: 'Look, we cook à la carte, we respect ourselves and we're really not ok with you coming with this application [saying - my note] 'This is food on a discount!'. (C App 2)

In fact, C App 2 seems to have presumed the existence of a sort of common sense 
rule that what is cooked one day can be eaten (especially when it comes to large portions), but cannot be sold the next day: "It's not food that is about to expire, but food that was cooked today and that I don't want to sell tomorrow, because I don't think it is normal to do so." (C App 2).

App 2 had close to 500 registered users, with under 100 of them regularly placing orders. While 15 restaurants agreed in principle and signed contracts for the use of the application, only 4 of them uploaded offers. According to C App 2, the price of initial offers was not attractive enough for users to try the application out.

App 3 has just been launched, as a pilot in one of the supermarkets in Bucharest. In this case, the usage scenario, according to C App 3, would be that in which you are at home and you are preparing to cook for the family or for some friends and you check out the existing offers so you can get the best deal on your ingredients. As such, there would be two waves of users who come for the discounted produce: in the morning, those who are retired and budget conscious, in the afternoon, the rest. For those who are not on a tight budget, the offers promoted by App 3 would work as hooks to get them on premise, where they most likely would pick up other items as well. C App 3 is also aware of the problematic nature of qualifying food as discounted or about to expire:

There's this stain, a sort of scarlet letter [on the image of discounted food - my note] that I fail to understand. [...] Fresh food, and I'm referring here to fruit and vegetables, doesn't have a specific expiry date...it's just a matter of what it looks like. [...] You really don't know what's really fresh and what's not, anyway. (C App 3)

That is why App 3 stresses on the fact that it allows users to get the best deals on fresh produce, rather than putting its food saving food forward. On a side note, C App 3 pointed out that finding a good deal might be perceived as a positive skill, likely to boost consumers' self-esteem, much in the spirit of having somehow negotiated that deal themselves.

In the case of App 4, given its limited mission to simply connect donors to beneficiaries no discussion was possible concerning the beneficiaries' possible preferences, needs or perceptions of the quality of the food provided to them. 


\section{CONCLUSIONS}

This analysis of food-saving mobile phone applications' role in improving food access in Romania and in helping surface systemic issues of social inequality has revealed that, while these tools mediate communication around and the idea of surplus redistribution, they do not aim or have the force to trigger social change yet. That is why they are merely incipient forms of "Internet-enhanced food activism", as defined in the literature review section.

In the case of the mobile applications considered, the precedence that monetization takes over donation within their business model is strongly influenced by a mix of heavy bureaucracy, inexistent infrastructure, non-sustainable financing and missing legal/tax incentives that would have to be overcome by any economic actor wishing to redistribute its surplus for the benefit of those in need. They do ensure a wider access to food for some users who are budget-conscious, while still affording to buy food, but only as a collateral rather than as an intended effect. Discussions with the owners/creators of such apps revealed that they are aware of, but do not take active responsibility in combating hunger as well; in other words, they feel that their apps have reached their purpose at the point where food is no longer thrown away, while its possible redistribution to those in need is above and beyond such purpose.

Further research about digital food activism might be worth undertaking as the Romanian online world becomes a platform where users can contribute and effect social change. One possible relationship to be monitored in this context might be the one tying urban dwellers to specific farms that sell eco or bio produce and poultry via Facebook pages and the evolution of food prices and branding as the respective providers gain notoriety and a constant consumer base. 


\section{REFERENCES}

Akamai (2017). Q1 2017 State of the Internet / Connectivity Report. Retrieved from: https://www.akamai.com/us/en/about/our-thinking/state-of-the-internet-report/global-state-of-the-internet-connectivity-reports.jsp

Broadbent, S., \& Francesco, C. (2018). Seeking Control in a Precarious Environment: Sustainable Practices as an Adaptive Strategy to Living under Uncertainty. Sustainability, 2018, 10, 1320. doi:10.3390/su10051320

Breniuc, I. (June 2016). EAT SMART: 'Are Expiry Dates the Greatest Enemy of Food Waste?' Green Report. Retrieved from https://www.green-report.ro/termenulde-valabilitate-risipa-alimentara/

Breniuc, I. (November 2016). Romalimenta: The Anti- Food Waste Law Might Fuel Tax Evasion Circuits. Green Report. Retrieved from https://www.green-report. ro/romalimenta-risipa-alimentara/

CeRe \& Somaro (2018). Open letter to the Romanian Chamber of Deputies concerning Law Project PL-x -573/2017 for the amendment of Law no. 217/2016 concerning the reduction of food waste. Retrieved from http://cere.ong/wp-content/uploads/2018/06/Scrisoare Lege diminuarea risipei-cu-semnatari.pdf

Cummins, S., \& Macintyre S. (1999). The location of food stores in urban areas: a case study in Glasgow. British Food Journal. 1999. 101:545-553

Donation Matching Software. (2018). Retrieved from https://www.refed.com/solutions/donation-matching-software

Edwards, F., \& Mercer, D. (2013). Food waste in Australia: the freegan response. In Evans, D., Campbell, H., \& Murcott, A. (Eds.). Waste matters: new perspectives on food and society. (pp. 174-191). Hoboken, NJ, USA: Wiley-Blackwell.

Eurostat (2016) Waste Statistics. Retrieved from http://ec.europa.eu/eurostat/statistics-explained/index.php/Waste statistics

Evans, D., Campbell H., \& Murcott, A. (2013). A brief pre-history of food waste and the social sciences. The Sociological Review, 60:S2, 5-26. 
Feeding America. (2014, December 19). Feeding America to Use New Technology for Local Food Rescue with $\$ 1.6 \mathrm{M}$ Google Global Impact Award [press release] Retrieved from http://www.feedingamerica.org/about-us/press-room/feedingamerica-wins-google-impact-award.html

Fight food waste and support local shops. (2018). Retrieved from https://yourlocal. org/en/

Gille, Z. (2013). From risk to waste: global food waste regimes. The Sociological Review, 60:S2, 27- 46 .

Lachat du "juste à temps" pour réduire le gaspillage alimentaire. (2018). Retrieved from https://www.optimiam.com/index.html

Lambie-Mumford, H. (2017). Hungry Britain The Rise of Food Charity. Bristol, UK: Policy Press

Law 217 of 2016 concerning the reduction of food waste (version adopted in May 2017) (2016) Retrieved from https://lege5.ro/Gratuit/geztknjtha3q/legea-nr217-2016-privind-diminuarea-risipei-alimentare

Law Project for the amendment of Law 217 of 2016 concerning the reduction of food waste (2018). Retrieved from http://www.cdep.ro/pls/proiecte/upl pck2015. proiect?idp $=16473$

Levkoe, C. Z. (2006). Learning democracy through food justice movements. In Counihan, C. \& Van Esterik, P. (eds.). Food and Culture. A Reader Third Edition, (pp. 587 - 602). London, UK: Routledge

Lo, J. (2018, June 28). 5 Apps Helping to End Hunger and Food Waste. Global Citizen, Retrieved from https://www.globalcitizen.org/en/content/hunger-food-wasteapps/

Mann, A. (2018). Hashtag activism and the right to food in Australia. In Schneider T, Eli, K., Dolan, C., \& Ulijaszek, S. Digital Food Activism (Critical Food Studies), (pp. 168-183). New York, NY, USA:Routledge, Kindle Edition

Milne, R. (2013). Arbiters of waste: date labels, the consumer and knowing good, safe food. The Sociological Review, 60:S2, 84-101 
Click to Feed. Mobile Phone Applications’ Role in Improving Food Access in Romania

O'Brien, M. (2013) A 'lasting transformation' of capitalist surplus: from food stocks to feedstocks. The Sociological Review, 60:S2 ( pp. 192-211). doi:10.1111/1467$\underline{954 X .12045}$

Poppendieck, J. (1998) Sweet Charity? Emergency Food and the End of Entitlement. London, UK: Penguin Books

Riches G., \& Silvasti, T. (2014) Hunger in the Rich World: Food Aid and Right to Food Perspectives. In Riches, G. \& Silvasti, T. (Eds.), First World Hunger Revisited Food Charity or The Right To Food? Second Edition, (pp. 1-14). London, UK: Palgrave Macmillan

Romania Against Food Waste. (2017). Retrieved from http://www.premiilepentrumediucurat.ro/wp-content/uploads/2016/11/147886440316015.pdf

Rousseau, S. (2013). Food and Social Media: You Are What You Tweet. Plymouth, UK: AltaMira Press.

Shannon, J. (2015). Rethinking Food Deserts Using Mixed-Methods GIS. Cityscape. Urban Problems and Spatial Methods, 17(1), 85-96.

Schneider T, Karin Eli, Catherine Dolan, \& Stanley Ulijaszek (2018). Introduction Digital Food Activism - food transparency one byte/bite at a time? In Schneider, T., Eli, K., Dolan, K. \& Ulijaszek, S., (Eds.), Digital Food Activism (Critical Food Studies) (pp. 1-23). New York, NY, USA: Routledge, Kindle Edition.

Schneider, T., Eli, K., Dolan, K., \& Ulijaszek, S. (2018). Digital food activism Values, expertise and modes of action. In Schneider, T., Eli, K., Dolan, K., \& Ulijaszek, S. (Eds.), Digital Food Activism (Critical Food Studies) (pp. 202-219). New York, NY, USA:Routledge, Kindle Edition.

Statista (2018). Forecast of the mobile internet user penetration rate in Romania from 2015 to 2022. Retrieved from https://www.statista.com/statistics/567853/ predicted-mobile-internet-user-penetration-rate-in-romania/

The World Bank (WB). (2017). Reaping Digital Dividends: Leveraging the Internet for Development in Europe and Central Asia. Retrieved from https://www. worldbank.org/en/region/eca/publication/digital-dividends-in-eca 
Wilson, A.D. (2012). Beyond alternative: exploring the potential for autonomous food spaces. Antipode. DOI:10.IIII/j.1467.8330.2012.01020.x

We're Too Good To Go. (n.d.). Retrieved from https://toogoodtogo.co.uk/about-us

What is Food Waste. (2016). Retrieved from http://foodwaste.ro/ce-este-risipa-dehranal

Wosskow, D. (2014). Unlocking the sharing economy. An independent review. retrieved from http://collaborativeeconomy.com/wp/wp-content/uploads/2015/04/Wosskow-D.2014.Unlocking-the-UK-Sharing-Economy.pdf

Zéro-Gâchis, qu'est ce que c'est?. (2011-2016). Retrieved from https://zero-gachis. com/fr/le-service 